\title{
Response Based Comparative Analysis of Two Inverter Fed Six Phase PMSM Drive by Using PI and Fuzzy Logic Controller
}

\author{
Anurag Singh Tomer ${ }^{1}$, Satya Prakash Dubey ${ }^{2}$ \\ ${ }^{1}$ College of Agriculture Engineering and Technology \& Research Station, Mungeli, \\ Indira Gandhi Krishi Vishwavidyalay, Raipur, India \\ ${ }^{2}$ Rungta Colllege of Engineering and Technology, Bhilai, India
}

\begin{tabular}{l} 
Article Info \\
\hline Article history: \\
Received May 9, 2016 \\
Revised Oct 20, 2016 \\
Accepted Dec 2, 2016 \\
\hline
\end{tabular}

Keyword:

Drive

Fuzzy logic controller

Inverter

PI controller

PMSM

\begin{abstract}
This Paper gives a complete modeling and simulation of a two inverter fed six phase permanent magnet synchronous motor drive system, Then response based comparative analysis is done on starting torque ,settling time, Steady state current at various speed levels and torque levels by changing proportional-integral (PI) controller to Fuzzy logic controller. The PI controller has some disadvantages like, more settling time, sluggish response due to sudden change in load torque etc. So an intelligent controller, based on fuzzy logic is introduced which replaces the PI-controller and its drawbacks. The performance of both the controller has been investigated and studied by comparing the different plots obtained by setting various speed level both incremented and decremented speed, at different load conditions like Noload, fix load and dynamic load through Matlab / Simulink environment. Finally it is concluded from the result that fuzzy logic based controller is robust, reliable gives quick response with high starting torque and more effective than the conventional PI controller. It is also observed that both the proposed model can also run above rated speed significantally.
\end{abstract}

Copyright (c) 2016 Institute of Advanced Engineering and Science. All rights reserved.

Corresponding Author:

Anurag Singh Tomer,

College of Agriculture Engineering and Technology \& Research Station, Mungeli, Indira Gandhi Krishi Vishwavidyalay, Raipur, India

Email: tomeranu@yahoo.com

\section{INTRODUCTION}

Since past few decades power electronics has been widely used in drive or as energy generation/conversion system. It can be said that electrical machines with power electronics converter connected are in a mature state. Even After, When it is about selecting a machine on the basis of reducing the current per phase without increasing the voltage per phase, reducing the rotor harmonic currents, reducing the amplitude and increasing the frequency of torque pulsations, and lowering the dc-link current harmonics and higher reliability, it is always Multiphase variable speed drive [1-5].

Multiphase variable speed PMSM drive has received tremendous interest because of its advantages of being multiphase and superiority over other motor drive system. This growing interest is due to the fact that this machine can provide noticeable improvements in performance related to various aspects when compared to either three phase DC drive or six phase induction motor drive [6-9].

Two kinds of six phase systems are available symmetrical and asymmetrical. The first is symmetrical system in which stator windings are either $0^{\circ}$ or $60^{\circ}$ apart. In which zero degree phase shift is similar to three phase system. The most common is asymmetrical system in which the stator winding is composed of two sets of 3-phase windings, in Figure 1, which are spatially apart by $30^{\circ}$ [10-11]. 

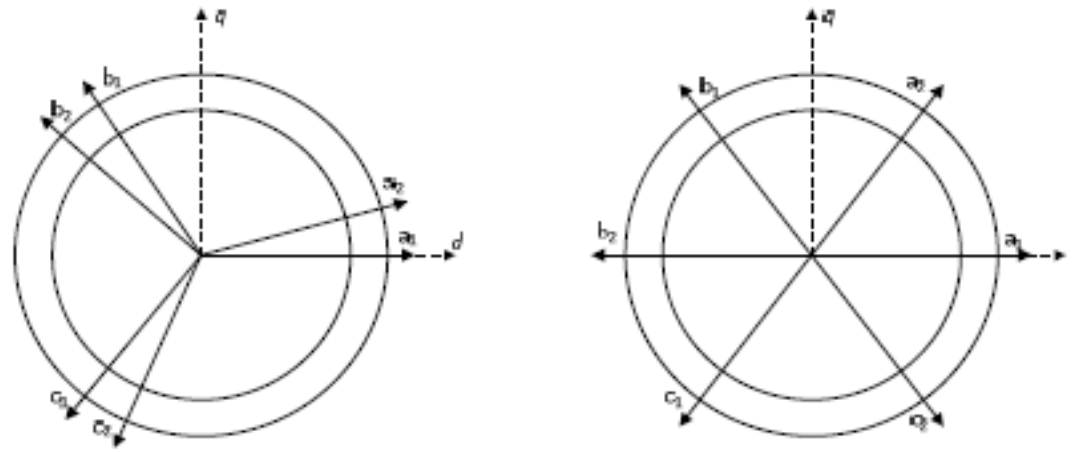

Figure 1. Stator winding in symmetrical and asymmetrical machine

This paper concentrate on complete modeling and simulation of asymmetrical dual inverter fed 6-phase PMSM drive system controlled by traditional PI and Fuzzy logic controller at various speed levels. Vector control (FOC) is one of the ideal techniques used for the control of such drive system. Here two loops are formed the outer loop and the inner loop. The outer loop greatly affects the drive performance. Therefore the electrical drives good dynamic performance is mandatory so as to respond the changes in command speed and torques. The Proportional-Integral controller is one of the traditional controllers which are widely used in many drive system. It maintains a zero steady state error to a sudden step change in reference. Simultaneously it has some disadvantages like undesirable speed overshoot, long settling time, the sluggish response due to sudden change in load torque and the sensitivity to controller gains $\mathrm{Ki}_{\mathrm{I}}$ and $\mathrm{Kp}$. These problems can be overcome by the fuzzy logic controllers which do not require any mathematical model and are based on the linguistic rules obtained from the experience of the system operator [12-13].

\section{MODELING OF SIX PHASE PMSM}

In developing the mathematical model the following assumptions and equations are used [14]:

a. The capacitance can be neglected

b. The set of stator windings are symmetrical.

c. Distributed windings may be represented by a concentrated winding.

d. The change in the inductance of the stator windings is sinusoidal and free from higher order harmonics.

e. Core losses are neglected.

f. The magnetic circuits are linear i.e. not saturated and the values of inductance are independent of the current.

In this study, a six-phase PMSM with two three-phase Windings is adopted where $A B C$ winding is spatially 30 electrical degrees phase led to $X Y Z$ winding. The phase voltage and flux linkage equations in the stationary reference frame for $A B C$ winding and $X Y Z$ winding of six-phase PMSM are shown as:

$$
\begin{aligned}
& V_{A B C}=R_{S} I_{A B C}+\frac{d \phi_{A B C}}{d t} \\
& \phi_{A B C}=L_{11} I_{A B C}+L_{12} I_{X Y Z}+\phi_{M A B C}^{\prime} \\
& V_{X Y Z}=R_{S} I_{X Y Z}+\frac{d \phi_{X Y Z}}{d t} \\
& \phi_{X Y Z}=L_{22} I_{X Y Z}+L_{21} I_{A B C}+\phi_{M X Y Z}^{\prime}
\end{aligned}
$$

where $R_{s}=\operatorname{diag}\left[R_{s}, R_{s}, R_{s}\right]^{T}$ is the stator resistance vector; $V_{A B C}=\left[V_{A} V_{B} V_{C}\right]^{T}$ is the phase voltage vector of $A B C$ winding; $I_{A B C}=\left[I_{A} I_{B} I_{C}\right]^{T}$ is the current vector of $A B C$ winding; $V_{X Y Z}=\left[V_{X} V_{Y} V_{Z}\right]^{T}$ is the phase voltage vector of $X Y Z$ winding; $I_{X Y Z}=\left[I_{X} I_{Y} I_{Z}\right]^{T}$ is the current vector of $X Y Z$ winding; $\varnothing_{A B C}=\left[\varnothing_{A} \emptyset_{B} \varnothing_{C}\right]^{T}$ is the stator flux linkage vector of $A B C$ winding; $\emptyset_{\mathrm{XYZ}}=\left[\varnothing_{\mathrm{X}} \emptyset_{\mathrm{Y}} \varnothing_{\mathrm{Z}}\right]^{\mathrm{T}}$ is the stator flux linkage vector of XYZ

IJECE Vol. 6, No. 6, December $2016: 2643-2657$ 
winding; $\mathbf{L}_{11}$ is the stator inductance vector of win $A B C$ winding; $L_{22}$ is the stator inductance vector of $X Y Z$ winding; $\mathbf{L}_{\mathbf{1 2}}$ and $\mathbf{L}_{\mathbf{2 1}}$ are the mutual inductance vectors; $\varnothing^{\prime}{ }_{\mathrm{MABC}}{ }^{\prime}$ ' is the permanent-magnet flux linkage vector of $\mathrm{ABC}$ winding; $\varnothing^{\prime}{ }_{\mathrm{MXYZ}}$ is the permanent-magnet flux linkage vector of XYZ winding. In order to control the six-phase PMSM, the following Transformation matrixes have been used to transfer the above Equations into the synchronous rotating reference frame:

$$
\begin{gathered}
T q d \mathrm{l}=\frac{2}{3}\left[\begin{array}{ccc}
\cos \theta_{e} & \cos \left(\theta_{e}-120^{\circ}\right) & \cos \left(\theta_{e}+120^{\circ}\right) \\
\sin \theta_{e} & \sin \left(\theta_{e}-120^{\circ}\right) & \sin \left(\theta_{e}+120^{\circ}\right) \\
\frac{1}{2} & \frac{1}{2} & \frac{1}{2}
\end{array}\right] \\
T q d 2=\frac{2}{3}\left[\begin{array}{ccc}
\cos \left(\theta_{e}-30^{0}\right) & \cos \left(\theta_{e}-150^{\circ}\right) & \cos \left(\theta_{e}+90^{\circ}\right) \\
\sin \left(\theta_{e}-30^{\circ}\right) & \sin \left(\theta_{e}-150^{\circ}\right) & \sin \left(\theta_{e}+90^{\circ}\right) \\
\frac{1}{2} & \frac{1}{2} & \frac{1}{2}
\end{array}\right]
\end{gathered}
$$

where $\mathrm{T}_{q d 1}$ is the transformation matrix for $A B C$ winding; $\mathrm{T}_{q d 2}$ is the transformation matrix for $X Y Z$ winding; $\theta_{e}$ is the rotor flux angle. Moreover, the machine model of a six-phase PMSM can be described in synchronous rotating reference frame as follows:

$$
\begin{aligned}
& v_{q 1}=R_{s} I_{q 1}+L_{q 11} \frac{d I_{q 1}}{d t}+\omega_{e}\left(L_{d 11} I_{d 1}+\phi_{P M}\right) \\
& v_{d 1}=R_{s} I_{d 1}+L_{d 11} \frac{d I_{d 1}}{d t}-\omega_{e} L_{q 11} I_{q 1} \\
& v_{q 2}=R_{s} I_{q 2}+L_{q 22} \frac{d I_{q 2}}{d t}+\omega_{e}\left(L_{d 22} I_{d 2}+\phi_{P M}\right) \\
& v_{d 2}=R_{s} I_{d 2}+L_{d 22} \frac{d I_{d 2}}{d t}-\omega_{e} L_{q 22} I_{q 2} \\
& \omega_{e}=\frac{P}{2} \omega_{r}
\end{aligned}
$$

where $v_{d 1}$ and $v_{q 1}$ are the $d$ - $q$ axis voltages of $A B C$ winding; $v_{d 2}$ and $v_{q 2}$ are the $d-q$ axis voltages of $X Y Z$ winding; $i_{d 1}$ and $i_{q 1}$ are the $d-q$ axis currents of $A B C$ winding; $i_{d 2}$ and $i_{q 2}$ are the $d-q$ axis currents of XYZ winding; $L_{d 11}$ and $L_{q 11}$ are the $d-q$ axis inductances of $A B C$ winding; $L_{d 22}$ and $L_{q 22}$ are the $d-q$ axis inductances of $X Y Z$ winding; $\omega_{r}$ is the rotor angular velocity; $\omega_{\mathrm{e}}$ is the electrical angular velocity; $\varnothing_{\mathrm{PM}}$ is the permanent magnet flux linkage; $\mathrm{P}$ is the no. of pole pairs of six phase PMSM. As assumed that winding sets are identical $\left(\mathrm{L}_{\mathrm{q} 11}=\mathrm{L}_{\mathrm{q} 22}=\mathrm{L}_{\mathrm{q}}\right.$ and $\left.\mathrm{L}_{\mathrm{d} 11}=\mathrm{L}_{\mathrm{d} 22}=\mathrm{L}_{\mathrm{d}}\right)$. Furthermore, the developed electric torque Te can be represented by the following equation:

$$
T_{e}=\frac{3}{2} \frac{P}{2}\left[\phi_{P M}\left(I_{q 1}+I_{q 2}\right)+\left(L_{d}-L_{q}\right)\left(I_{d 1} I_{q 1}+I_{d 2} I_{q 2}\right)\right]
$$

However, the electromagnetic torque cannot be estimated accurately in a general case without knowledge of the currents of both winding sets and the inductance parameters that describe the magnetic coupling between them. In addition, the mechanical dynamic equation of the six-phase PMSM is:

$$
T_{e}=J \frac{d \omega_{r}}{d t}+B \omega_{r}+T_{L}
$$

where $J$ is the inertia of six-phase PMSM; $B$ is the damping Coefficient; $T_{L}$ is the load torque. The machine parameter for the above modeling is given in Table 1 [15]. 
Table 1. Machine Parameter

\begin{tabular}{lll}
\hline S. NO. & NAME & RATING \\
\hline 1. & Nominal voltage $V_{\mathrm{n}}$ & 380 volts \\
2. & Nominal speed $n_{\mathrm{n}}$ & $350 \mathrm{RPM}(36.5 \mathrm{rad} / \mathrm{s})$ \\
3. & No. of Poles & 8 \\
4. & Stator Resistance Rs & $0.64 \mathrm{ohm}$ \\
5. & PM flux Linkage $\emptyset_{\mathrm{PM}}$ & $2.04 \mathrm{wb}$ \\
6. & $\mathrm{~L}_{\mathrm{d}}, \mathrm{L}_{\mathrm{q}}$ & $24 \mathrm{mH}, 31.4 \mathrm{mH}$ \\
7. & Inertia J & $.014 \mathrm{Nm} /\left(\mathrm{rad} / \mathrm{sec}^{2}\right)$ \\
8. & Damping coefficient B & $.0124 \mathrm{Nm} /(\mathrm{rad} / \mathrm{sec})$ \\
\hline
\end{tabular}

The modeling in simulink (MATLAB) of Six phase PMSM is presented in following Figure 2.

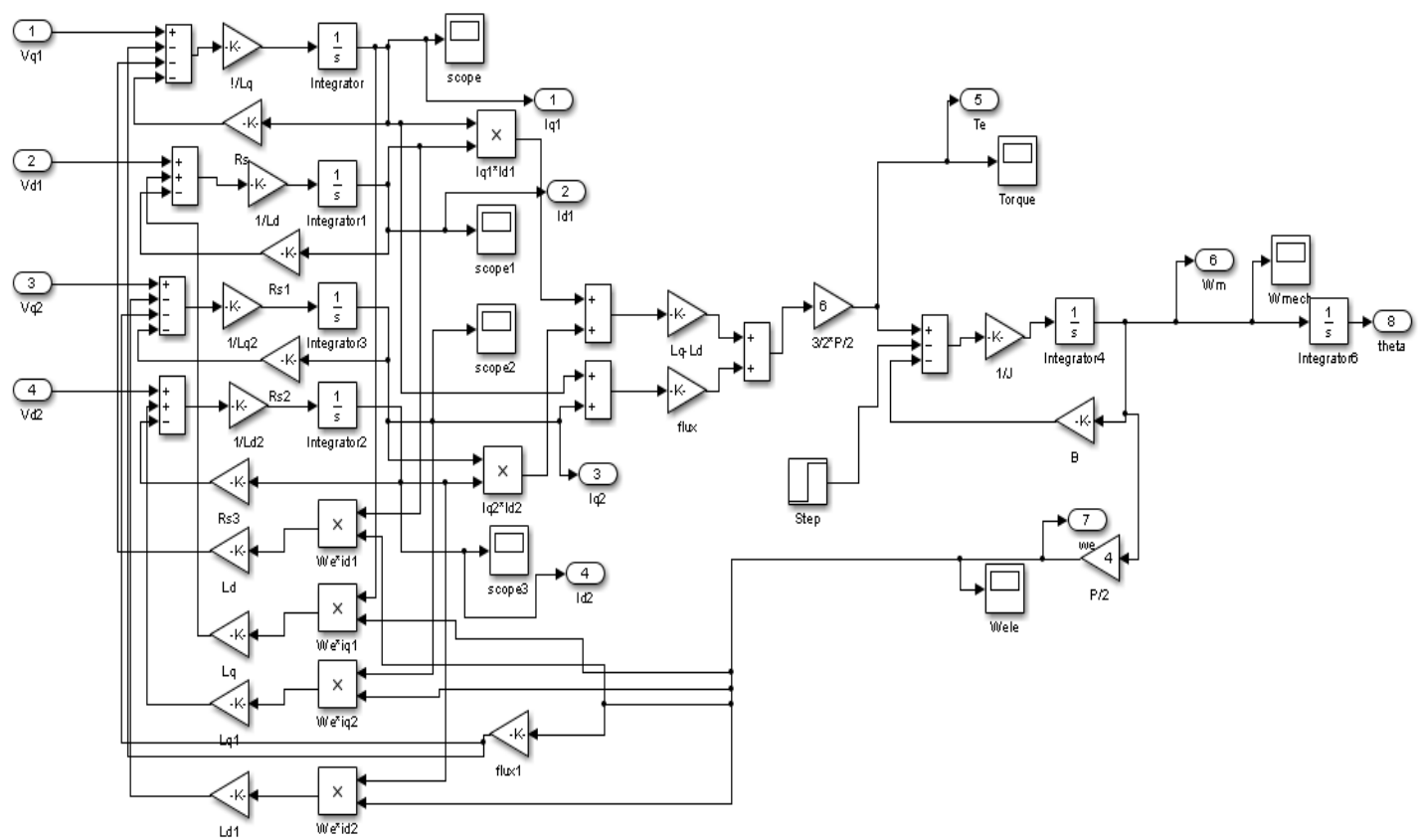

Figure 2. Matlab/Simulink Model of Six Phase PMSM.

\section{CONTROLLER SCHEMES}

The difference between the desired input $\left(\omega_{\text {mref }}\right)$ and the actual output $\left(\omega_{\text {mact }}\right)$ is a variable $\Delta \omega_{\mathrm{r}}$ which is known as tracking error. This tracking error signal is send to controller which generates iq* known q-axis command current. This output of controller and $i_{\mathrm{d}} *(=0)$ are transformed to $\mathrm{ABC}$ and XYZ current command using inverse park's transform. These command currents are now compared with the actual currents to generate the PWM signals which will than fire the semiconductor devices to produce actual voltages for Six Phase motor to operate properly Figure 3. 


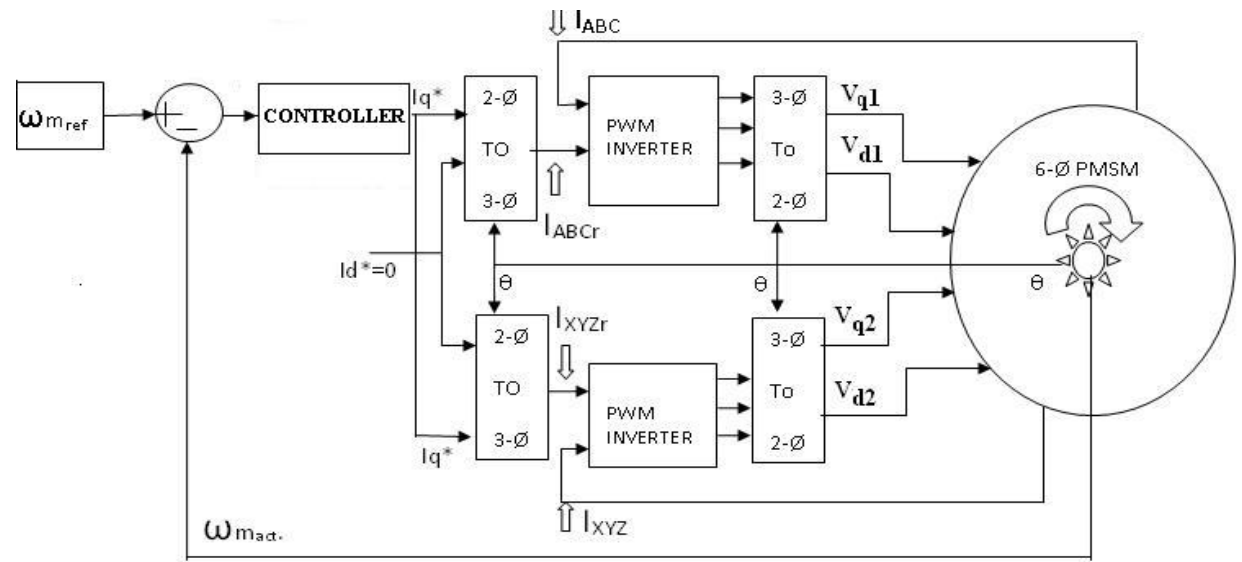

Figure 3. Block Diagram Of Six Phase PMSM drive

\subsection{Proportional- Integral Controller (PI)}

The PI controller produces an output signal consisting of two terms- one proportional to input signal and the other proportional to the integral of input signal. The concerns of PI controller in the system are to reduce the steady state error and increased the order and type of the system by one which is shown in Figure 4 [16].

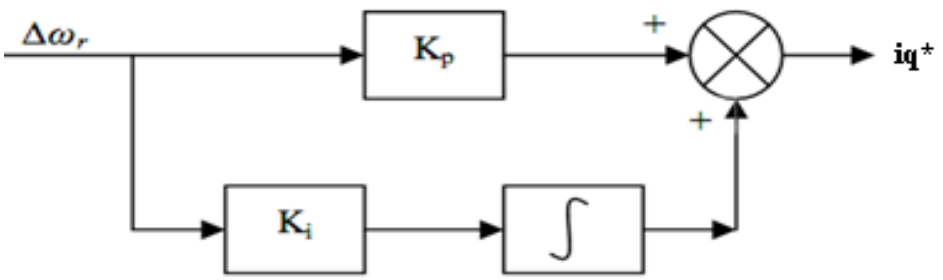

Figure 4. PI Controller

Transfer function $P I=K_{p}+\frac{K_{i}}{S}$

$$
i_{q^{*}}=K_{p} \Delta \omega_{r}+K_{i} \int \Delta \omega_{r} d t
$$

This iq* is than sent further in the system to control the operation of Six Phase PMSM drive system as shown in block diagram in Figure 3 for tuning of PI controller Closed Loop Ziegler-Nichols Method is used. Since it is trial and error method it is time consuming. Initially a random value of $\mathrm{Kp}$ and $\mathrm{Ki}$ is chosen then after seeing the improvements in response of the model, the most suitable value of $\mathrm{Kp}$ and $\mathrm{Ki}$ is selected.

\subsection{Fuzzy Logic Controller}

Initially the fuzzy input vector should be defined. It consists of two variables; the speed error $e(t)=\omega_{\text {ref }} *-\omega_{\text {mact }}$ and its derivative $\frac{d[e(t)]}{d t}=\frac{d}{d t}\left(\omega_{\text {ref }} *-\omega_{\text {mact }}\right)$. A fuzzy set for input and output variables is designed. Figure 5(a) and Figure 5(b), shows the seven linguistic variables used for each fuzzy input variable, while the output variable fuzzy set is shown in Figure 5. The linguistic variables used for inputs shown are PS (Positive Small), PM (Positive Medium); PB (Positive Big); ZE (Zero); NB (Negative Big); and NM (Negative Medium), NS (Negative Small) the same LV's are used for the output fuzzy set. A look-up table is required to develop the set of rules, in which the relation between the input variables, e(t) and $\mathrm{d}[\mathrm{e}(\mathrm{t})\} / \mathrm{dt}]$ are defined and the output variable of fuzzy logic controller can be obtained 16. To define the control rules, the results from PI controller give an opportunity and guidance for rule justification 
Therefore after thorough series of analysis; the total 49 rules have been justified as shown in Table 2 this look-up table is used in the simulation program [17-19].

The Input/output depends on the fuzzy rule expressed as follows;

If ( $\mathrm{E}$ is NB AND CE is NB) THEN Iq* is NB. If (E is Z AND CE in PS) THEN Iq* is PS

In total 49 fuzzy rules are made to meet the goal.

\section{Table 2. Fuzzy Rule Look Up Table}

\begin{tabular}{llllllll}
\hline$\underset{\mathrm{CE}}{\mathrm{C}}$ & & & & & & & \\
& $\mathrm{NB}$ & $\mathrm{NM}$ & $\mathrm{NS}$ & $\mathrm{Z}$ & $\mathrm{PS}$ & $\mathrm{PM}$ & $\mathrm{PB}$ \\
& & & & & & & \\
\hline NB & NB & NB & NB & NB & NM & NS & Z \\
NM & NB & NB & NB & NM & NS & Z & PS \\
NS & NB & NB & NM & NS & Z & PS & PM \\
Z & NB & NM & NS & Z & PS & PM & PB \\
PS & NM & NS & Z & PS & PM & PB & PB \\
PM & NS & Z & PS & PM & PB & PB & PB \\
PB & Z & PS & PM & PB & PB & PB & PB \\
\hline
\end{tabular}

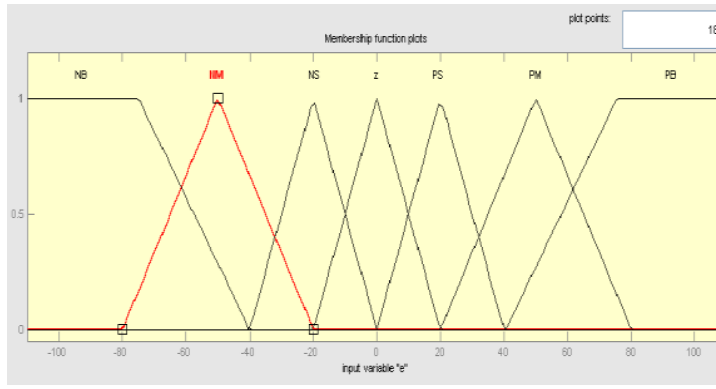

(a) Error

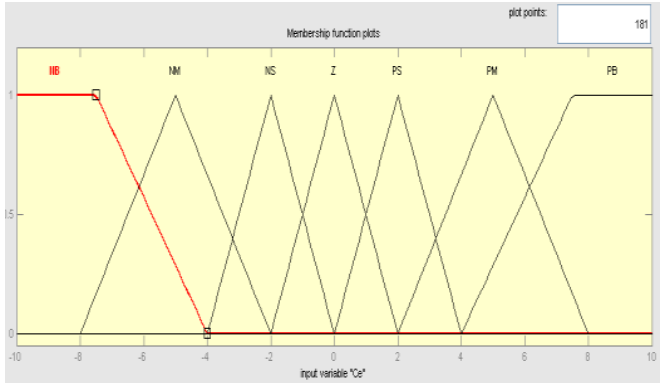

(b) Change in Error

Figure5. (a), (b) Membership Function Plots, the Input Error ' $e$ ' and Change in Error ' $\Delta \mathrm{e}$ '

Membership function plot for Output variable iq* is shows in Figure 6.

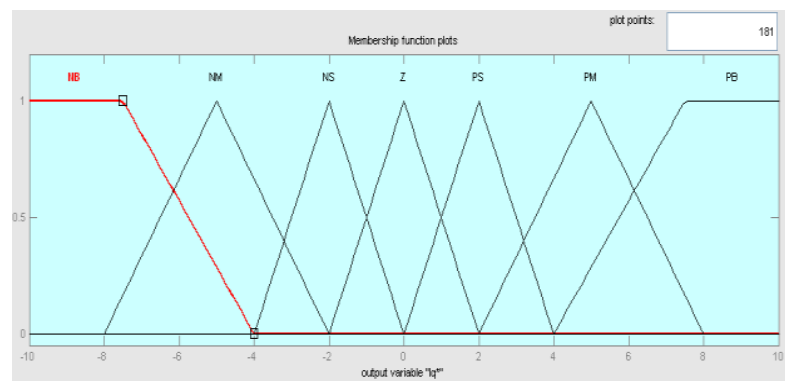

Figure 6. Membership Function Plot for Output Variable iq* 
Fuzzy logic based controller is shows in Figure 7.

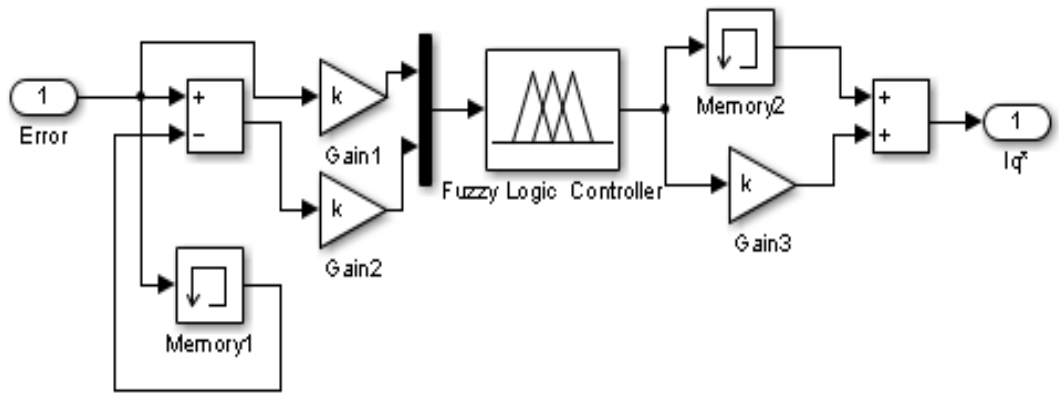

Figure 7. Fuzzy Logic Based Controller

\section{RESULT AND DISCUSSION}

\subsection{Case I: when Speed is set at 36.5 rps (rated speed)}

\subsubsection{Load Torque is Fixed $T_{L}=150 N-M$}

The model is simulated at fix load Torque $\left(\mathrm{T}_{\mathrm{L}}=150 \mathrm{~N}-\mathrm{M}\right)$ and at rated speed $\left(\omega_{\mathrm{r}}=36.5 \mathrm{rad} / \mathrm{sec}.\right)$. Figure 8 and Figure 9 shows torque response, rotor speed and six phase current respectively for both the proposed scheme.

The simulation results show that at 0.015-0.02 sec. Speed and Torque reaches, it's set value for Fuzzy controller, and for PI controller the settling time is delayed at $0.08-0.09 \mathrm{sec}$. The value of initial torque is $312 \mathrm{~N}-\mathrm{M}$ for PI controller and $1250 \mathrm{~N}-\mathrm{M}$ for fuzzy controller.the value of steady state max current is $8.76 \mathrm{~A}$ and 8.79A respectively for PI and fuzzzy logic based controller.

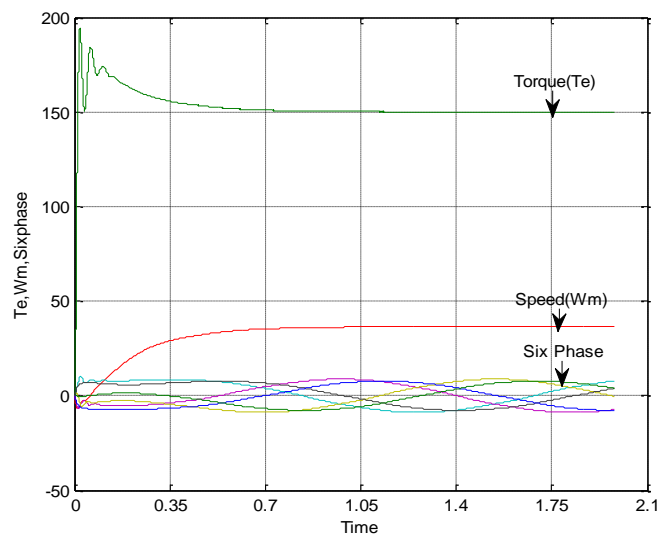

Figure 8. Torque, Speed \& Sixphase in PI Controller (Rated Speed \& Fix Load)

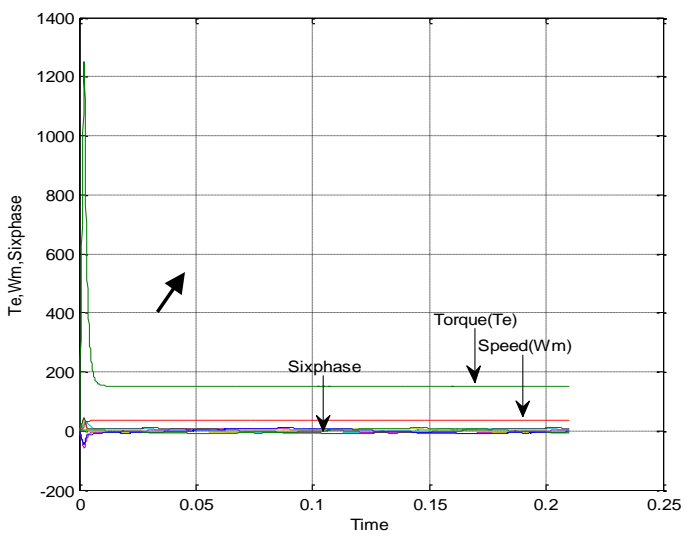

Figure 9. Torque, Speed \& Sixphase in Fuzzy Controller (Rated Speed \& Fix Load)

\subsubsection{Dynamic Operation $T_{L}=0$ to $T_{L}=150 \mathrm{~N}-\mathrm{M}$ at Instance $0.12 \mathrm{sec}$}

The model has been simulated for dynamic load operation; load torque is initially set to zero and at $0.12 \mathrm{sec}$. load torque is suddenly changed to $150 \mathrm{~N}-\mathrm{M}$. Figure 10 and Figure 11 shows that when load Torque is applied suddenly at $0.12 \mathrm{sec}$. (From $\mathrm{T}_{\mathrm{L}}=0$ to $\mathrm{T}_{\mathrm{L}}=150 \mathrm{~N}-\mathrm{M}$ ). In PI controller the speed falls very heavily $(25.5 \mathrm{rps})$. The recovery time of rotor speed to come back to set rated speed ( $36.5 \mathrm{rps})$ after 0.08 sec. While in Fuzzy controller the speed falls very slightly (35.6 rps) and recovers very fastly (after .004 sec). The value of initial torque is $213 \mathrm{~N}-\mathrm{M}$ for PI controller and $1088 \mathrm{~N}-\mathrm{M}$ for fuzzy controller. The value of steady state max current is $6.09 \mathrm{~A}$ and $8.76 \mathrm{~A}$ for PI controller \& 3.5A and 8.9A for fuzzzy logic based controller. 


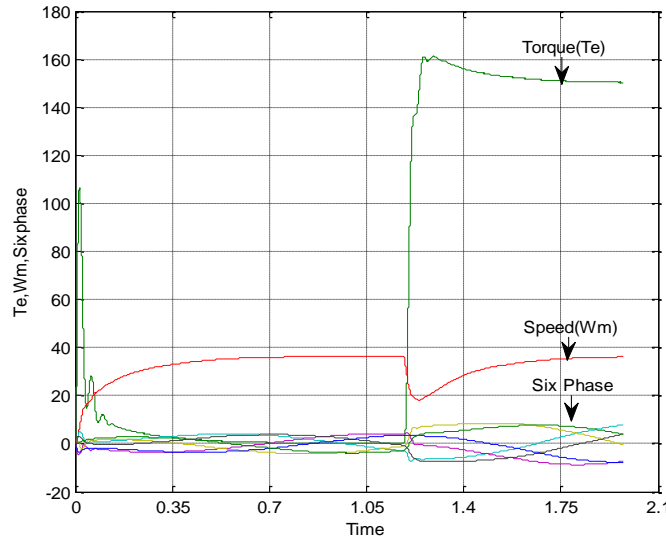

Figure 10. Torque, Speed \& Sixphase in PI Controller (Rated speed \& Dynamic Load)

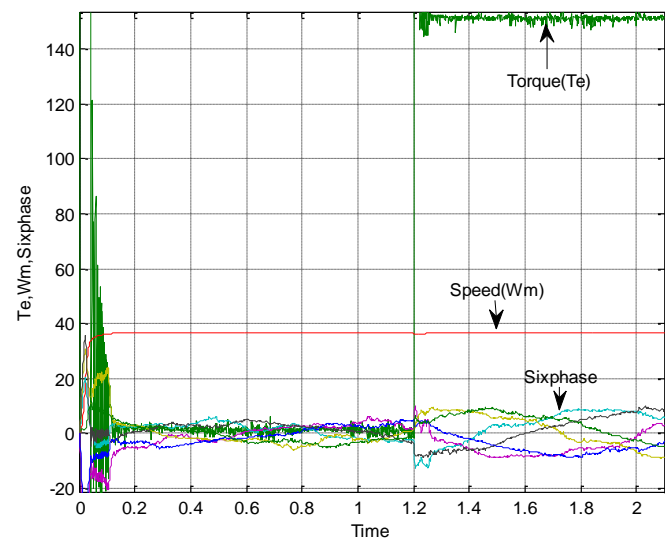

Figure 11. Torque, Speed \& Sixphase in Fuzzy Controller (Rated Speed \& Dynamic Load)

\subsection{Case II: when Speed is $20 \%$ Increased to that of Rated Speed}

\subsubsection{Load Torque is Fixed $T_{L}=150 \mathrm{~N}-M$}

The model is simulated at fix load Torque $\left(\mathrm{T}_{\mathrm{L}}=150 \mathrm{~N}-\mathrm{M}\right)$ and at $20 \%$ increased rated speed Figure 12 and Figure 13 shows torque response, rotor speed and six phase current respectively for both the proposed scheme. The simulation results show that at 0.015-0.02 sec. Speed and Torque reaches, it's set value for Fuzzy controller, and for PI controller it is delayed till 0.08-0.09 sec. The value of initial torque is $353 \mathrm{~N}-\mathrm{M}$ for PI controller and 1413N-M for fuzzy controller. The value of steady state max current is $9.45 \mathrm{~A}$ and 10.2A respectively for PI and fuzzy logic based controller.

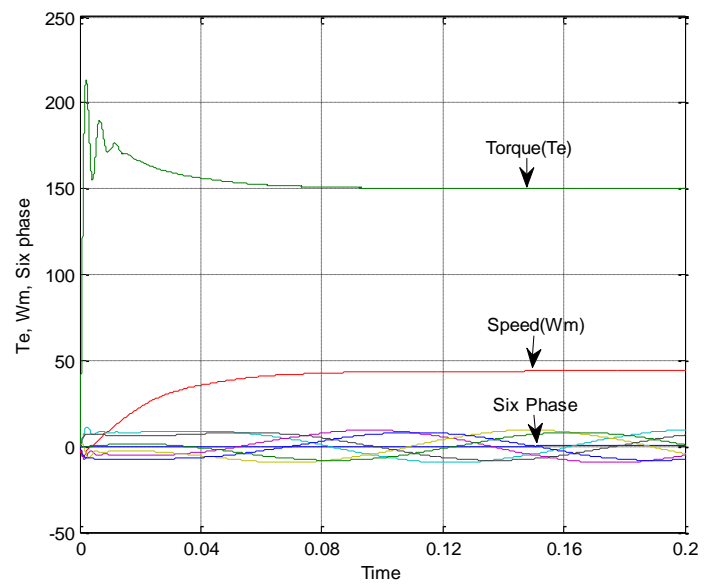

Figure 12. Torque, Speed \& Sixphase in PI Controller (120\% Rated Speed \& Fix Load)

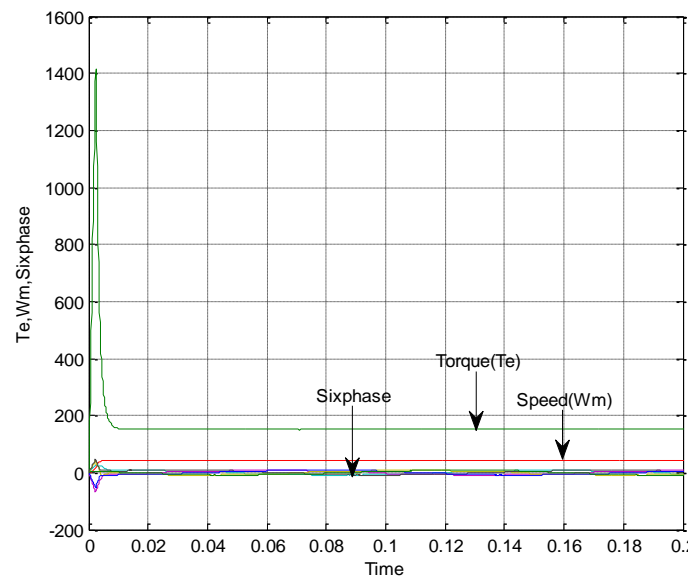

Figure 13. Torque, Speed \& Sixphase in Fuzzy Controller (120\% Rated Speed \& Fix Load)

\subsubsection{Dynamic Operation $T_{L}=0$ to $T_{L}=150 \mathrm{~N}-M$ at Instance $0.12 \mathrm{sec}$}

The model has been simulated for dynamic load operation; load torque is initially set to zero and at $0.12 \mathrm{sec}$. load torque is suddenly changed to $150 \mathrm{~N}-\mathrm{M}$. Figure 14 and Figure 15 shows that when load Torque is applied suddenly at $0.12 \mathrm{sec}$. (From $\mathrm{T}_{\mathrm{L}}=0$ to $\mathrm{T}_{\mathrm{L}}=150 \mathrm{~N}-\mathrm{M}$ ). In PI controller the speed falls very heavily (31 rps). The recovery time of rotor speed to come back to set speed $(36.5 \mathrm{rps})$ between $0.08-0.09 \mathrm{sec}$. While in Fuzzy controller the speed falls very slightly (36.06 rps) and recovers very fastly (after $0.004 \mathrm{sec}$ ). The value of initial torque is $256 \mathrm{~N}-\mathrm{M}$ for PI controller and $1250 \mathrm{~N}-\mathrm{M}$ for fuzzy controller. The value of steady state max current is 6.09A and 9.45A for PI controller \& 3.64A and 10.2A for fuzzy logic based controller. 


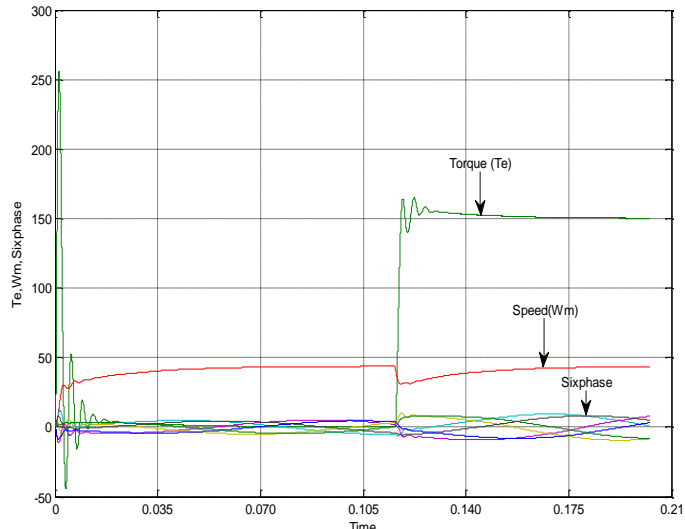

Figure 14. Torque, Speed \& Sixphase in PI controller (120\% Rated speed \& Dynamic Load)

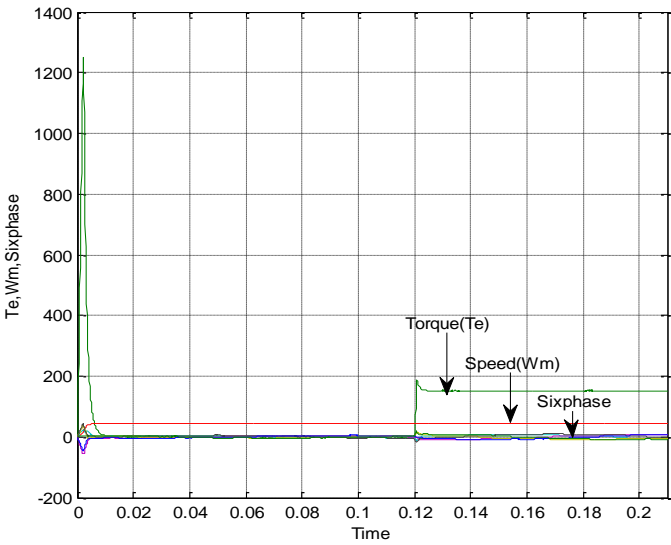

Figure 15. Torque, Speed \& Sixphase in F uzzy controller (120\% Rated speed \& Dynamic Load)

\subsection{Case III: when Speed is $40 \%$ increased to that of Rated Speed}

\subsubsection{Load Torque is Fixed $T_{L}=150 N-M$}

The model is simulated at fix load Torque $\left(\mathrm{T}_{\mathrm{L}}=150 \mathrm{~N}-\mathrm{M}\right)$ and at $40 \%$ increased rated speed Figure 16 and Figure 17 shows torque response, rotor speed and six phase current respectively for both the proposed scheme. The simulation results show that at 0.015-0.02 sec. Speed and Torque reaches, it's set value for Fuzzy controller, and for PI controller it reaches till 0.08-0.09 sec. The value of initial torque is $394 \mathrm{~N}-\mathrm{M}$ for PI controller and $1535 \mathrm{~N}-\mathrm{M}$ for fuzzy controller. The value of steady state max current is 7.06A and 8.6A respectively for PI and fuzzy logic based controller.

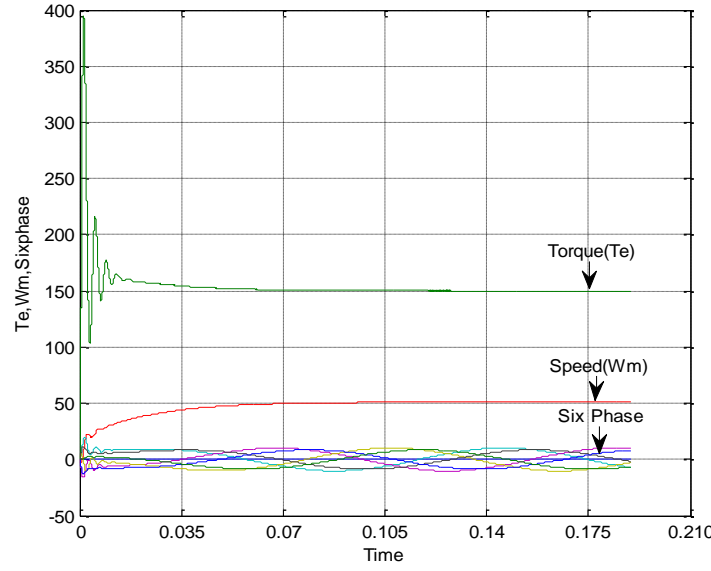

igure 16. Torque, Speed \& Sixphase in PI Controller (140\% Rated speed \& Fix Load)

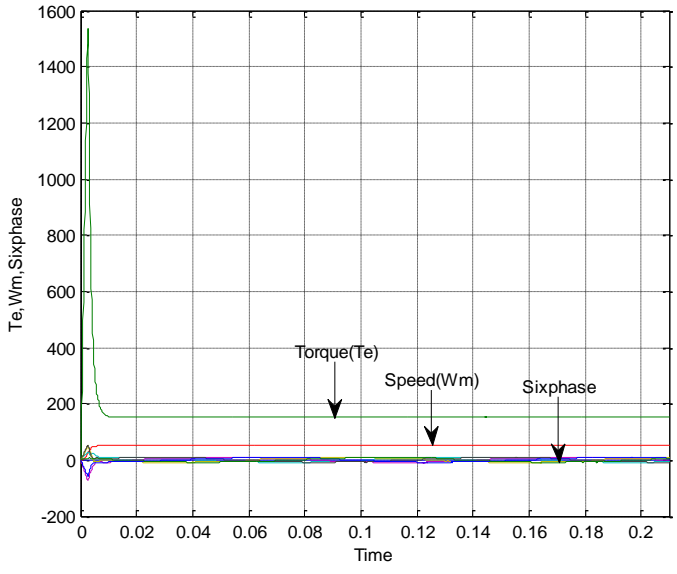

Figure 17. Torque, Speed \& Sixphase in Fuzzy Controller (140\% Rated speed \& Fix Load)

\subsubsection{Dynamic Operation $T_{L}=0$ to $T_{L}=150 \mathrm{~N}-\mathrm{M}$ at Instance $0.12 \mathrm{sec}$}

The model has been simulated for dynamic load operation; load torque is initially set to zero and at $0.12 \mathrm{sec}$. Load torque is suddenly changed to $150 \mathrm{~N}-\mathrm{M}$. Figure 18 and Figure 19 shows that when load Torque is applied suddenly at $0.12 \mathrm{sec}$. (From $\mathrm{T}_{\mathrm{L}}=0$ to $\mathrm{T}_{\mathrm{L}}=150 \mathrm{~N}-\mathrm{M}$ ). In PI controller the speed falls very heavily (38.7 rps). The recovery time of rotor speed to come back to set speed is between 0.08-0.09 secs. While in Fuzzy controller the speed falls very slightly and recovers very fastly (after .004 sec). The value of initial torque is $299 \mathrm{~N}-\mathrm{M}$ for PI controller and $1379 \mathrm{~N}-\mathrm{M}$ for fuzzy controller. The value of steady state max current is $6.09 \mathrm{~A}$ and $10.4 \mathrm{~A}$ for PI controller \& $6.2 \mathrm{~A}$ and $10.4 \mathrm{~A}$ for fuzzy logic based controller. 


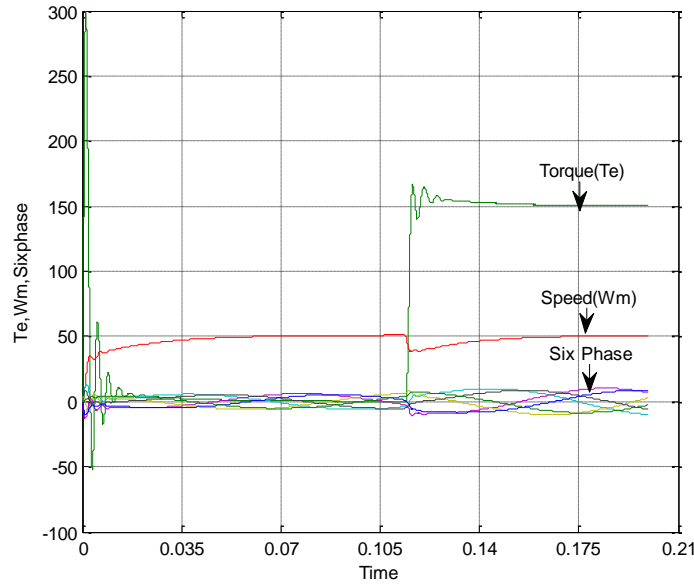

Figure 18. Torque, Speed \& Sixphase in PI Controller (140\% Rated Speed \& Dynamic Load)

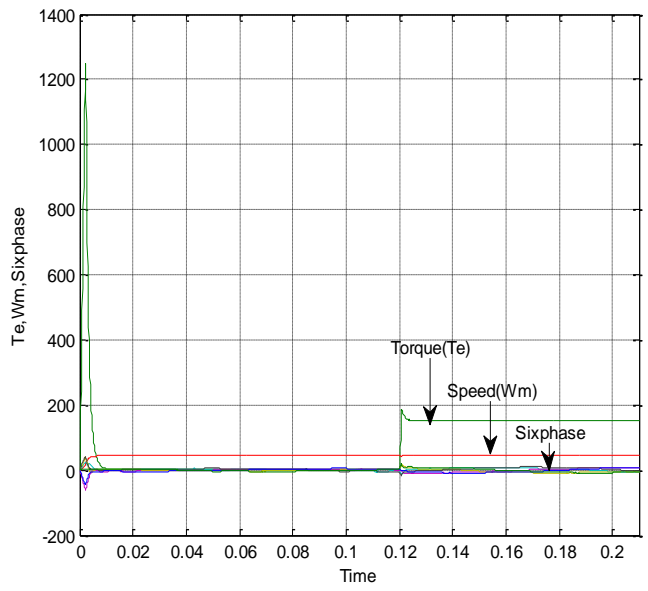

Figure 19. Torque, Speed \& Sixphase in Fuzzy Controller (140\% Rated Speed \& Dynamic Load)

\subsection{Case V: when Speed is $50 \%$ reduced to that of Rated Speed}

\subsubsection{Load Torque is Fixed $T_{L}=150 \mathrm{~N}-M$}

The model is simulated at fix load Torque $\left(\mathrm{T}_{\mathrm{L}}=150 \mathrm{~N}-\mathrm{M}\right)$ and at $50 \%$ decreased in rated speed Figure 20 and Figure 21 shows torque response, rotor speed and six phase current respectively for both the proposed scheme. The simulation results show that at 0.015-0.02 sec. Speed and Torque reaches, it's set value for Fuzzy controller, and for PI controller it is delayed till $0.08-0.09 \mathrm{sec}$. The value of initial torque is $216 \mathrm{~N}-\mathrm{M}$ for PI controller and $827 \mathrm{~N}-\mathrm{M}$ for fuzzy controller. The value of steady state max current is $7.06 \mathrm{~A}$ and 8.6A respectively for PI and fuzzy logic based controller.

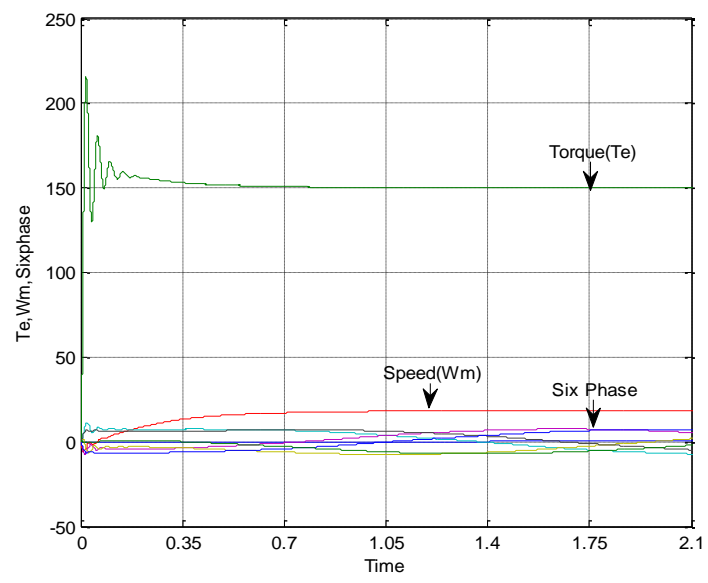

Figure 20. Torque, Speed \& Sixphase in PI Controller (50\% Rated Speed \& Fix Load)

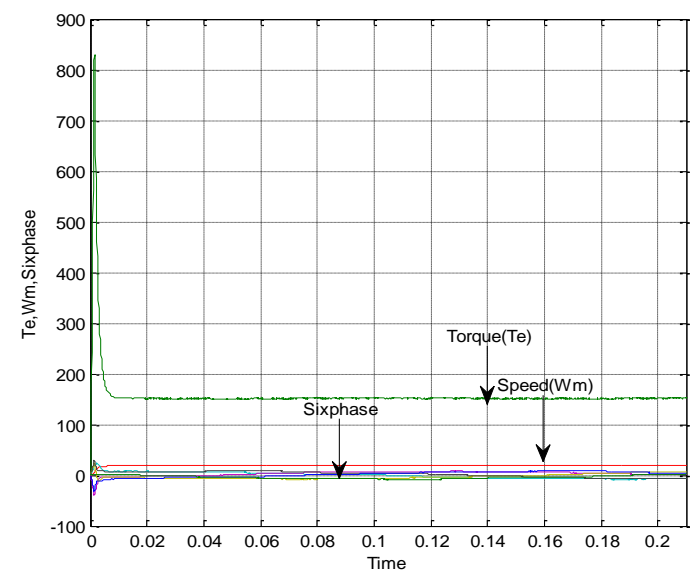

Figure 21. Torque, Speed \& Sixphase in Fuzzy Controller (50\% Rated Speed \& Fix Load)

\subsubsection{Dynamic Operation $T_{L}=0$ to $T_{L}=150 \mathrm{~N}-\mathrm{M}$ at Instance $0.12 \mathrm{sec}$}

The model has been simulated for dynamic load operation; load torque is initially set to zero and at $0.12 \mathrm{sec}$. Load torque is suddenly changed to $150 \mathrm{~N}-\mathrm{M}$. Figure 22 and Figure 23 shows that when load Torque is applied suddenly at $0.12 \mathrm{sec}$. (From $\mathrm{T}_{\mathrm{L}}=0$ to $\mathrm{T}_{\mathrm{L}}=150 \mathrm{~N}-\mathrm{M}$ ). In PI controller the speed falls very heavily (17.8 rps). The recovery time of rotor speed to come back to set speed between 0.08-0.09 sec. While in Fuzzy controller the speed falls very slightly $(21.5 \mathrm{rps}$ ) and recovers very fastly (after $0.004 \mathrm{sec}$ ). The value of initial torque is $106 \mathrm{~N}-\mathrm{M}$ for PI controller and $681 \mathrm{~N}-\mathrm{M}$ for fuzzy controller. The value of steady state max current 1.9A and 7.06A for PI controller \& 2.3A and 8.6A for fuzzy logic based controller. 


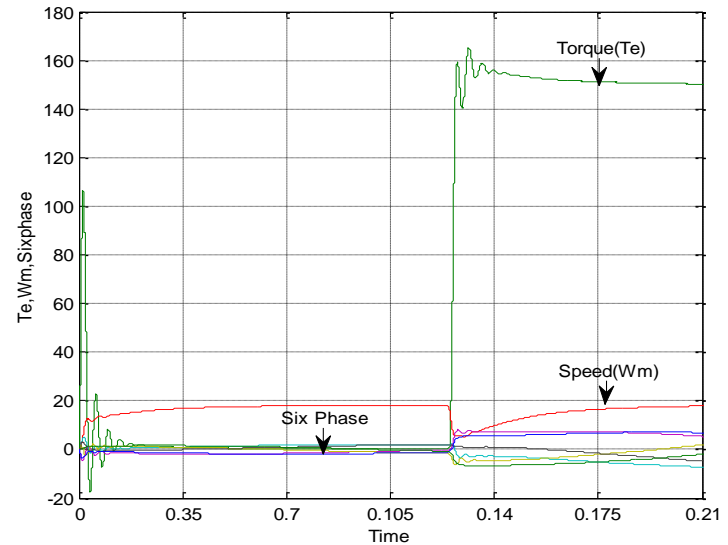

Figure 22. Torque, Speed \& Sixphase in PI controller (50\% Rated Speed \& Dynamic Load)

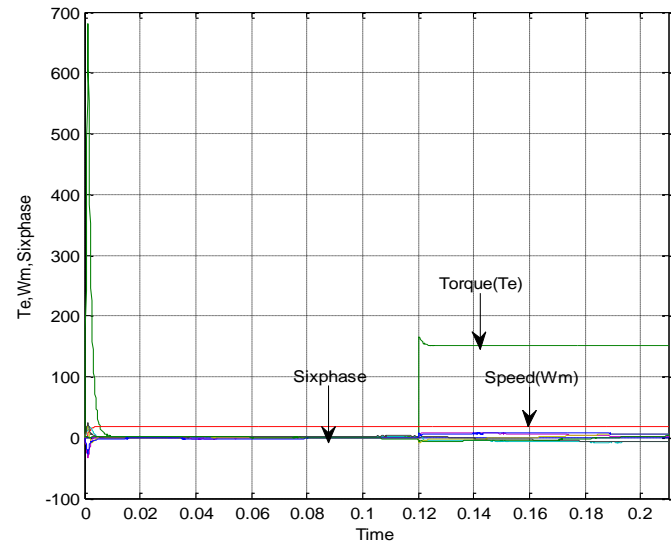

Figure 23. Torque, Speed \& Sixphase in Fuzzy controller (50\% Rated Speed \& Dynamic Load)

\subsection{Case VI: when Speed is $20 \%$ reduced to that of Rated Speed}

\subsubsection{Load Torque is Fixed $T_{L}=150 \mathrm{~N}-M$}

The model is simulated at fix load Torque $\left(\mathrm{T}_{\mathrm{L}}=150 \mathrm{~N}-\mathrm{M}\right)$ and at $20 \%$ decreased rated speed Figure 24 and Figure 25 shows torque response, rotor speed and six phase current respectively for both the proposed scheme. The simulation results show that at 0.015-0.02 sec. Speed and Torque reaches, it's set value for Fuzzy controller, and for PI controller it is delayed till 0.08-0.09 sec. The value of initial torque is $272 \mathrm{~N}-\mathrm{M}$ for PI controller and 1107N-M for fuzzy controller. The value of steady state max current is $8 \mathrm{~A}$ and 9.2A respectively for PI and fuzzy logic based controller.

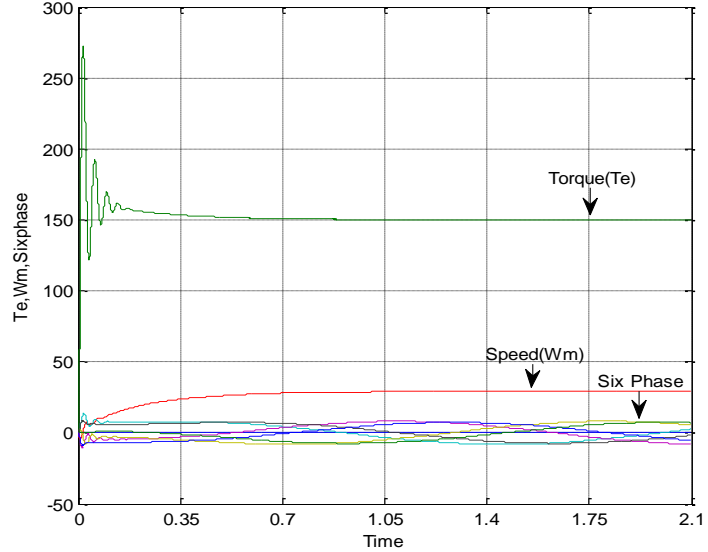

Figure 24. Torque, Speed \& Sixphase in PI controller (20\% Rated Speed \& Fix Load)

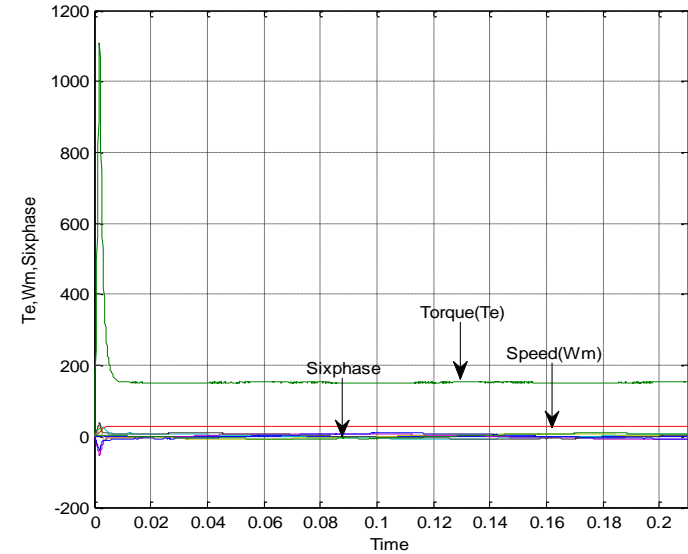

Figure 25. Torque, Speed \& Sixphase in Fuzzy controller (20\% Rated Speed \& Fix Load)

\subsubsection{Dynamic Operation $T_{L}=0$ to $T_{L}=150 \mathrm{~N}-\mathrm{M}$ at Instance $0.12 \mathrm{sec}$}

The model has been simulated for dynamic load operation; load torque is initially set to zero and at $0.12 \mathrm{sec}$. Load torque is suddenly changed to $150 \mathrm{~N}-\mathrm{M}$. Figure 26 and Figure 27 shows that when load Torque is applied suddenly at $0.12 \mathrm{sec}$. (From $\mathrm{T}_{\mathrm{L}}=0$ to $\mathrm{T}_{\mathrm{L}}=150 \mathrm{~N}-\mathrm{M}$ ). In PI controller the speed falls very heavily (16.35 rps). The recovery time of rotor speed to come back to set speed between $0.08-0.09$ sec. While in Fuzzy controller the speed falls very slightly and recovers very fastly (after $0.004 \mathrm{sec}$ ). The value of initial torque is $170 \mathrm{~N}-\mathrm{M}$ for PI controller and $937 \mathrm{~N}-\mathrm{M}$ for fuzzy controller. The value of steady state max current is 2.8A and 9A for PI controller \& 3A and 9.2A for fuzzy logic based controller. 


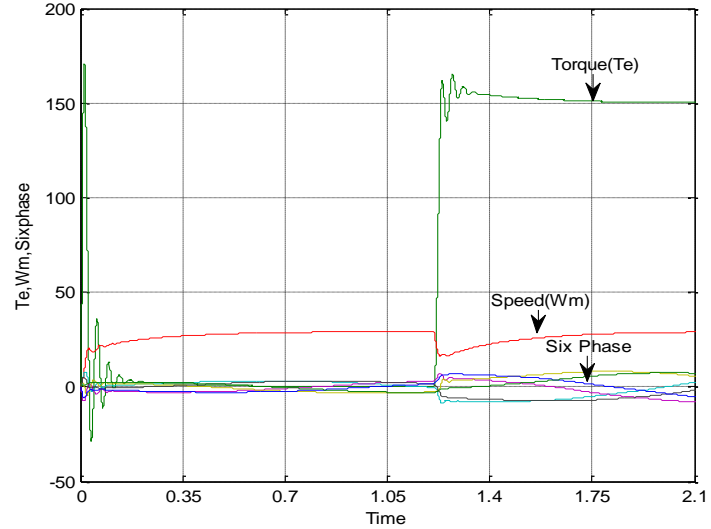

Figure 26. Torque, Speed \& Sixphase in PI Controller (20\% Rated Speed \& Dynamic Load)

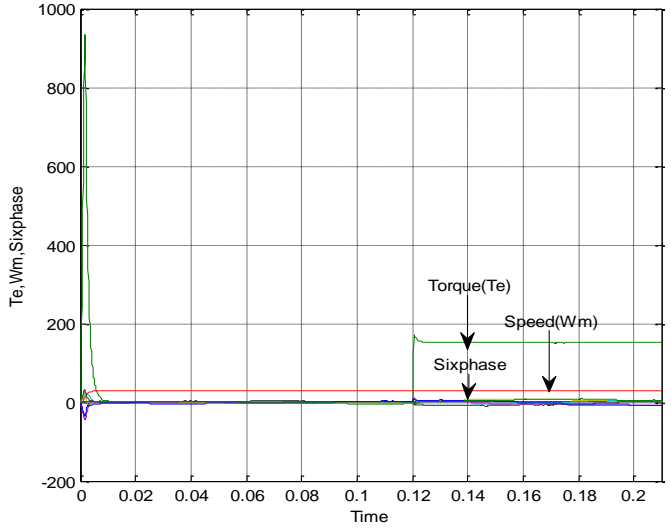

Figure 27. Torque, Speed \& Sixphase in Fuzzy Controller (20\% Rated Speed \& Dynamic Load)

\subsection{Case VII: when Speed is $40 \%$ reduced to that of Rated Speed}

\subsubsection{Load Torque is Fixed $T_{L}=150 N-M$}

The model is simulated at fix load Torque $\left(\mathrm{T}_{\mathrm{L}}=150 \mathrm{~N}-\mathrm{M}\right)$ and at $20 \%$ increased rated speed Figure 28 and Figure 29 shows torque response, rotor speed and six phase current respectively for both the proposed scheme. The simulation results show that at 0.015-0.02 sec. Speed and Torque reaches, it's set value for Fuzzy controller, and for PI controller it is delayed till 0.08-0.09 sec. The value of initial torque is $234 \mathrm{~N}-\mathrm{M}$ for PI controller and $940 \mathrm{~N}-\mathrm{M}$ for fuzzy controller. The value of steady state max current is $7.2 \mathrm{~A}$ and 9A respectively for PI and fuzzy logic based controller

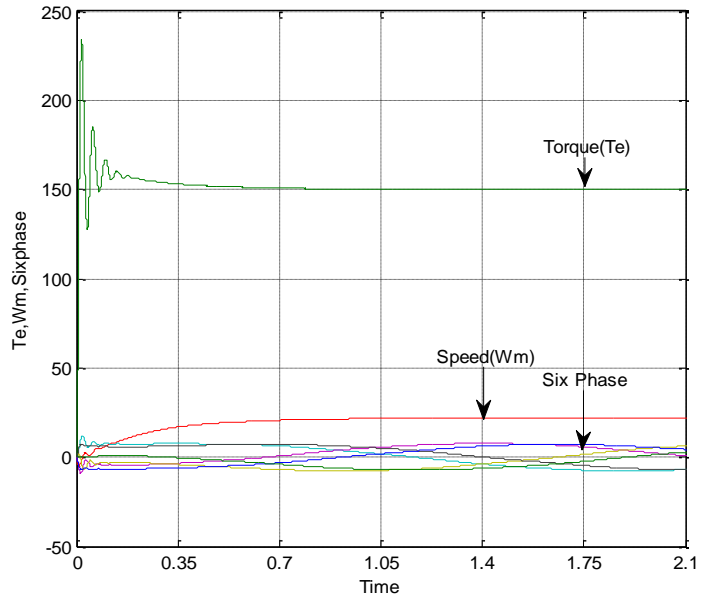

Figure 28. Torque, Speed \& Sixphase in PI controller (40\% Rated Speed \& Fix Load)

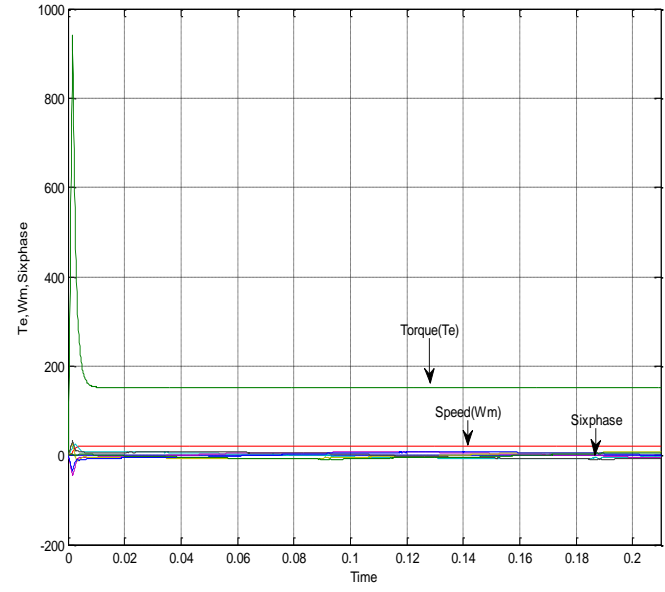

Figure 29. Torque, Speed \& Sixphase in PI Controller (40\% Rated Speed \& Fix Load)

\subsubsection{Dynamic Operation $T_{L}=0$ to $T_{L}=150 \mathrm{~N}-\mathrm{M}$ at Instance $0.12 \mathrm{sec}$}

The model has been simulated for dynamic load operation; load torque is initially set to zero and at $0.12 \mathrm{sec}$. Load torque is suddenly changed to $150 \mathrm{~N}-\mathrm{M}$. Figure 30 and Figure 31 shows that when load Torque is applied suddenly at $0.12 \mathrm{sec}$. (From $\mathrm{T}_{\mathrm{L}}=0$ to $\mathrm{T}_{\mathrm{L}}=150 \mathrm{~N}-\mathrm{M}$ ). In PI controller the speed falls very heavily $(8.85 \mathrm{rps})$. The recovery time of rotor speed to come back to set speed between $0.08-0.09$ sec. While in Fuzzy controller the speed falls very slightly and recovers very fastly (after $0.004 \mathrm{sec}$ ). The value of initial torque is $128 \mathrm{~N}-\mathrm{M}$ for PI controller and $770 \mathrm{~N}-\mathrm{M}$ for fuzzy controller. The value of steady state max current is 
2.31A and 7.2A for PI controller \& 2.2A and 9A for fuzzy logic based controller. Summary of result shows in Tablbe 3.

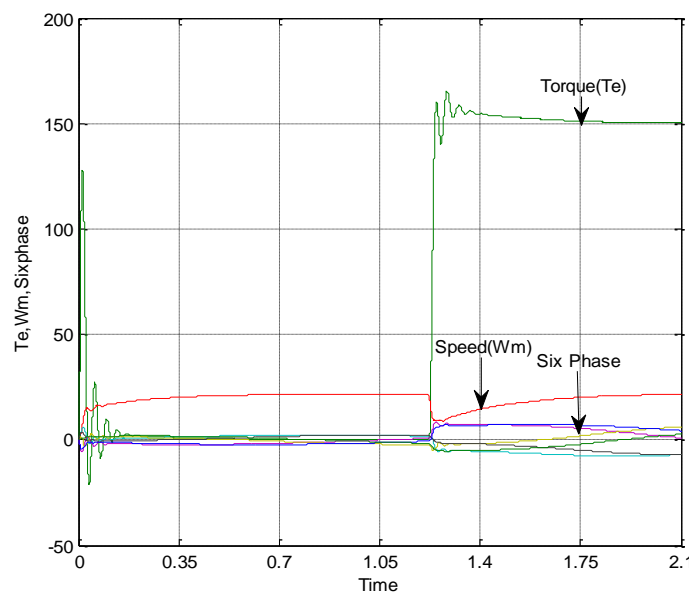

Figure 30. Torque, Speed \& Sixphase in PI Controller (40\% Rated Speed \& Dynamic Load)

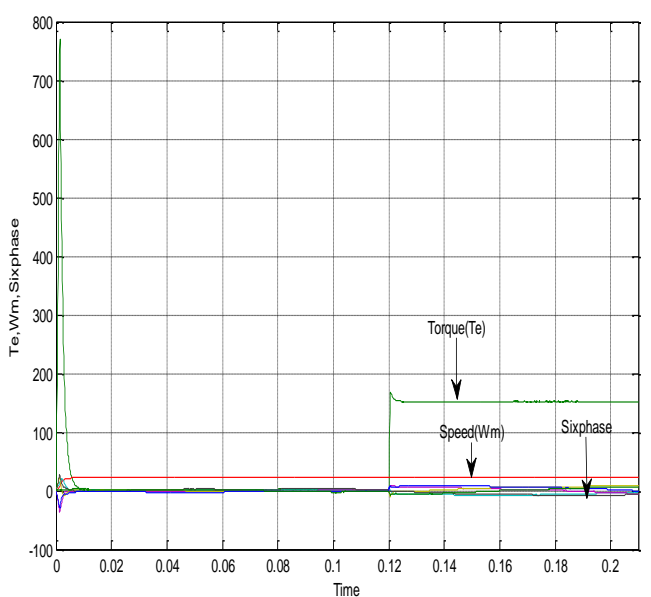

Figure 31. Torque, Speed \& Sixphase in Fuzzy Controller (40\% Rated Speed \& Dynamic Load)

Table 3. Summary of Result

\begin{tabular}{|c|c|c|c|c|c|c|}
\hline S.No. & Controller Type & Speed & Torque & $\begin{array}{l}\text { Settling } \\
\text { Time }\end{array}$ & $\begin{array}{l}\text { Starting } \\
\text { Torque }\end{array}$ & $\begin{array}{l}\text { Steady } \\
\text { Max.Current(A) }\end{array}$ \\
\hline \multirow[t]{4}{*}{1.} & \multirow[t]{2}{*}{ PI } & \multirow[t]{4}{*}{ Rated } & Fix load Torque & $0.08-0.09$ & 312 & 8.76 \\
\hline & & & Dynamic load Torque & $0.08-0.09$ & 213 & 6.09 and 8.76 \\
\hline & \multirow[t]{2}{*}{ FUZZY } & & Fix load Torque & $0.015-0.02$ & 1250 & 8.9 \\
\hline & & & Dynamic load Torque & $0.015-0.02$ & 1088 & 3.5 and 8.9 \\
\hline \multirow[t]{4}{*}{2.} & \multirow[t]{2}{*}{ PI } & \multirow{4}{*}{$\begin{array}{l}20 \% \\
\text { Increased }\end{array}$} & Fix load Torque & $0.08-0.09$ & 353 & 9.45 \\
\hline & & & Dynamic load Torque & $0.08-0.09$ & 256 & 6.09 and 9.45 \\
\hline & \multirow[t]{2}{*}{ FUZZY } & & Fix load Torque & $0.015-0.02$ & 1413 & 10.2 \\
\hline & & & Dynamic load Torque & $0.015-0.02$ & 1250 & 3.64 and 10.2 \\
\hline \multirow[t]{4}{*}{3.} & \multirow[t]{2}{*}{ PI } & \multirow{4}{*}{$\begin{array}{l}40 \% \\
\text { Increased }\end{array}$} & Fix load Torque & $0.08-0.09$ & 394 & 10.2 \\
\hline & & & Dynamic load Torque & $0.08-0.09$ & 299.87 & 6.09 and 10.2 \\
\hline & \multirow[t]{2}{*}{ FUZZY } & & Fix load Torque & $0.015-0.02$ & 1535 & 10.8 \\
\hline & & & Dynamic load Torque & $0.015-0.02$ & 1379 & 6.2 and 10.8 \\
\hline \multirow[t]{4}{*}{4.} & \multirow[t]{2}{*}{ PI } & \multirow{4}{*}{$\begin{array}{l}50 \% \\
\text { Decreased }\end{array}$} & Fix load Torque & $0.08-0.09$ & 216 & 7.06 \\
\hline & & & Dynamic load Torque & $0.08-0.09$ & 106.5 & 1.9 and 7.06 \\
\hline & \multirow[t]{2}{*}{ FUZZY } & & Fix load Torque & $0.015-0.02$ & 827 & 8.6 \\
\hline & & & Dynamic load Torque & $0.015-0.02$ & 681 & 2.3 and 8.6 \\
\hline \multirow[t]{4}{*}{5.} & \multirow[t]{2}{*}{ PI } & \multirow{4}{*}{$\begin{array}{l}20 \% \\
\text { Decreased }\end{array}$} & Fix load Torque & 0.08-0.09 & 272 & 8 \\
\hline & & & Dynamic load Torque & $0.08-0.09$ & 170 & 2.8 and 8 \\
\hline & \multirow[t]{2}{*}{ FUZZY } & & Fix load Torque & $0.015-0.02$ & 1107 & 9.2 \\
\hline & & & Dynamic load Torque & $0.015-0.02$ & 933 & 3.8 and 9.2 \\
\hline \multirow[t]{4}{*}{6.} & \multirow[t]{2}{*}{ PI } & \multirow{4}{*}{$\begin{array}{l}40 \% \\
\text { Decreased }\end{array}$} & Fix load Torque & $0.08-0.09$ & 234 & 7.2 \\
\hline & & & Dynamic load Torque & $0.08-0.09$ & 128 & 2.31 and 7.2 \\
\hline & \multirow[t]{2}{*}{ FUZZY } & & Fix load Torque & $0.015-0.02$ & 940 & 9 \\
\hline & & & Dynamic load Torque & $0.015-0.02$ & 770 & 2.2 and 9 \\
\hline
\end{tabular}

\section{CONCLUSION}

This paper shows the Comparison \& performance of conventional PI controller \& Fuzzy logic controller by setting different Speed levels both increasing and decreasing then simulation results are obtained under different load conditions. The results shows that speed and torque responses are better in Fuzzy logic based controller as compared to PI controller. Under different load conditions the steady state is reached quickly in fuzzy logic controller without dropping more speed and a very slight delay. It can be also seen from the diagram that fuzzy controller gives high starting torque approximately 4-6 times to that of 
conventional PI controller. With results obtained from simulation, it is clear that for the same operating condition the PMSM drive control using fuzzy controller technique gives better performance than the conventional PI controller.

\section{REFERENCES}

[1] T.J.E. Miller and M.I. McGilp, "Analysis of Multi-Phase Permanent Magnet Synchronous Machines", Glasgow, UK, 2009.

[2] Milanesi and Filippo, Design optimization and control strategies for Multiphase Tubular Linear Actuator. Vol. 32, 2009.

[3] Jussi Puranen, "Induction motor versus permanent magnet Synchronous motor in motion control `Applications: a comparative study", Lappeenranta University of Technology, Thesis 2006.

[4] Hichem Kesraoui, Hamdi Echeikh, Atif Iqbal, Med Faouzi Mimouni, "Five-Phase Permanent Magnetic Synchronous Motor Fed By Fault Tolerant Five Phase Voltage Source Inverter", IJECE, vol. 6 No. 5, Oct. 2016.

[5] Hamid, Leila Parsa, and A. Toliyat, "Multi-Phase Permanent Magnet Motor Drives", IEEE Trans., 2003, pp. 401408.

[6] R.G. Shriwastava, M.B. Diagavane, S.R. Vaishnav, "Literature Review of Permanent Magnet AC Motors Drive for Automotive Application", in Bulletin of Electrical Engineering and Informatics, Vol. 1, No. 1, March 2012, pp. 7-14.

[7] P. Pillay and R. Krishanan, "Modeling, simulation, and analysis of permanent-magnet motor drives part 1: The permanent magnet synchronous motor drive", IEEE Trans.Ind. Appl., vol. 25, no. 2, March-April 1989, pp. 265273.

[8] P. Pillay and R. Krishanan, "Application characteristics of permanent-magnet synchronous and brushless DC motor for servo drives", IEEE Trans. Ind. Appl., vol. 27, no. 5, Sep-Oct 1991, pp. 986-996.

[9] Marc Vila Mani, "A quick overview on rotatory Brush and Brushless DC Motors Motion Control Department", C./Llacuna 162, Barcelona Spain, 2005.

[10] Urs Kafader. (2010) Selecting Dc Brush and Brushless Motors. [Online]. Machinedesign.com

[11] T.A. Lipo, "A d-q model for six phase induction motor", 1980.

[12] Prof. Aziz Ahmed, Yogesh Mohan, Aasha Chauhan, and Pradeep Sharma, "Comparative Study of Speed Control of D.C.Motor Using PI, IP, and Fuzzy Controller", International Journal of Advanced Research in Computer and Communication Engineering, vol. 2, no. 7, 2013, pp. 2693-2697.

[13] Yifan Zhao and T.A. Lipo, "space vector PWM control of Dual three phase induction machine using vector space decomposition", IEEE Trans., vol. 31, no. 5, 1995.

[14] Anurag Singh Tomer and Satya Prakash Dubey, "Performance Analysis of Two Inverter Fed Six Phase PMSM Drive", in NUiCONE13, Ahmedabad, 2013.

[15] J. Karttunen, S. Kallio, P. Peltoniemi, P. Silventoinen, and O. Pyrhonen, "Dual Three-Phase Permanent Magnet Synchronous Machine Supplied by Two Independent Voltage Source Inverters", 2012, pp. 741-747.

[16] Anurag Singh Tomer S.P. Dubey, "Response Based Tunning of Proportional and Integral Constants in PI Controlled Six Phase PMSM Drive", IJCSE, vol. 3, no. 12, DEC 2015, pp. 23-28.

[17] Mohammed Shoeb Mohiuddin, "Performance comparison of conventional controller with Fuzzy logic controller using chopper circuit and Fuzzy tuned PID controller", IJEEI, Vol. 2, No. 4, 2014, pp. 189-200.

[18] Faa-Jeng Lin, Ying-Chih Hung A, and Takagi-Sugeno-Kang, "Fault-Tolerant Control of Six-Phase Motor Drive System Using Takagi- Sugeno-Kang Type Fuzzy Neural Network With Asymmetric Membership Function", 2011, pp. 1-14.

[19] Joeeta Anurag Tomer RP Dubey Anurag Singh Tomer, "Performance Comparison of Anesthesia Using Conventional PI And Fuzzy Logic Based Controller", GJPAM, vol. 11, no. 6, November 2015, pp. 4177-4195.

\section{BIOGRAPHIES OF AUTHORS}

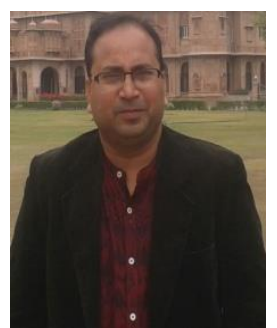

Er. Anurag Singh Tomer is presently working as scientist (Electrical Engineering) at Indira Gandhi Agricultural University; Raipur (C.G.). He is M.Tech in Electrical Engineering from NIT Raipur. His areas of reasearch are Artificial Intelligent, Drivecontrol, Modeling/Simuation, Multiphase Machines. Under his supervision many M.tech projects have been completed successfully. He is having experience of around fifteen years in the field of teaching and research. 


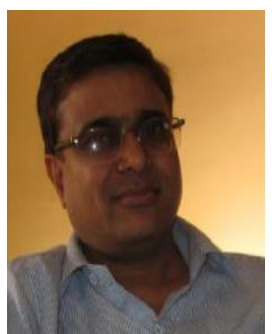

Dr. Satya Prakash Dubey Ex. Faculty member of IIT Roorkee is Presently working as Dean Research and Development at RCET, Bhilai (C.G.). He is Ph.D. in Electrical Engineering. He has many reseacrh projects under his belt. His areas of researche are filters, power electronics, Drives, Artificial intelligent, Multiphase machine analysis, Control System etc. He is having an experience of around 18 years in the field of teaching and research. 